\title{
ON THE SENONIAN AMMONITE FAUNA OF PONDOLAND.
}

\author{
By L. F. Sратн, D.Sc., F.G.S.
}

(With five Plates.)

\section{CONTENTS.}

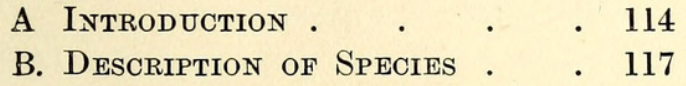

FAMILY PHYLLOCERATIDAE :

Genus Phylloceras, Suess:

1. Ph. woodsi, v. Hoepen . 117

2. Ph. umzambiense, $\nabla$.

$$
\text { Hoepen . . } 117
$$

FAMILY LYTOCERATIDAE :

Genus Gaddryceras, Grossouvre :

3. G. tenuilineatum, v. Hoepen . . . 117

$4 G$. varicostatum, v. Hoepen . . . 117

5. G. cinctum (Crick MS.), Spath . . . 118

6. G. amapondense, v. Hoepen . . . 118

7. G. sigcau, v. Hoepen . 118

Genus Tetragonites, Kossmat:

8. T. superstes, v. Hoepen. 119

9. T. nuperus, v. Hoepen . 119

Genus Pseudophyllites, Koss-

mat :

10. P. indra (Forbes). $\quad 119$

Family DESMOCERATIDAE :

Sub-Family PUZOSINAE :

Genus Parapuzosia, Nowak :

11. P. haughtoni, nov. • 128

Genus Schlüteria, Grossouvre :

12. S. simplex, v. Hoepen sp. 129

13. S. crassa, v. Hoepen sp. 129

Genus Hauericeras, Grossouvre :

14. H. gardeni, Baily sp. . 129

15. H. rembda, Forbas sp. . 131

16. H.? sugata, Forbes sp. . 131

10
SUB-FAMILY PACHYDISCINAE :

Genus Parapachydiscus, Hyatt :

17. P. aff. ootacodensis, Stoliczka sp. • • 132

18. P. simplex, v. Hoepen sp. . . . . 133

19. P. umtafunensis (Crick MS.), Spath 133

20. P. antecursor, v. Hoepen sp. . . . 133

21. P.? sp. nov.? . . 134

SUb-FAMILy KOSSMATICERATINAE :

Genus Madrasites, Kilian and

Reboul :

22. M. natalensis (Crick MS.), Spath • . . 134

23. M. acuticostatus (Crick MS.), Spath . 134

24. M. faku, v. Hoepen sp. . . . 135

25. M. africanus, v. Hoepen sp. . . . 135

26. $M$. aff. africanus, v. Hoepen sp. . . 135

27. M. sp. ind. . . . 135

28. M. similis, Spath. . 135

Incertae sedis-

Genus Hoploscaphites, Nowak :

29. $H$. sp. (ef. similaris, Stoliczka ?) • . 136

30. H. sp. (ef. pavana, Forbes ?) . 136

31. H. sp. nov.? . . 136

32. H. sp. ind. . . 136 
FAMILY 'PRIONOTROPIDAE' : Genus Mortoniceras, Meek :

33. M. soutoni, Baily sp. . 136

34. M. stangeri, Baily sp. . 137

35. M. stangeri (Baily), var. sparsicosta, nov.

36. M. stangeri (Baily), var. densicosta, nov.

Genus Pseudoschloenbachia, Spath :

37. P. umbulazi, Baily sp. . 139

38. P. pseudofournieri, nov. 140

39. P. papillata (Crick MS.), Spath • . . 141

40. P. griesbachi (Crick MS.), Spath . . . 141 Incertae sedis-

41. Gen. nov. (Muniericeras ?) cricki, Spath . 141

Genus Eulophoceras, Hyatt:

42. E. natalense, Hyatt .

Genus Spheniscoceras (Crick MS.), Spath . 142

43. S. africanum (Crick MS.), Spath

136
137
138
138
139
140
141
141
141
142
142

44. S. tenue (Crick MS.), Spath . . . 144

45. S. minor (Crick MS.), Spath . . . 144

46. S. amapondense, v. Hoepen sp. . . 144

47. S. umzambiense, v. Hoepen sp. . $\quad 145$

FAMILY NOSTOCERATIDAE:

Genus Bostrychoceras, Hyatt:

48. B. ? amapondense, v. Hoepen sp. . $\quad$. 145

Genus Diplomoceras, Hyatt: 49. D.? indicum (Forbes) - 145

Genus Oxybeloceras, Hyatt : 50. O. amapondense, v. Hoepen sp. . . 145

Genus Neocrioceras, Spath: 51. N. ef. spinigerum, Jimbo sp.

Genus Baculites, Lamarck:

52. B. capensis, Woods . 146

53. B. sulcatus, Baily · · 146

54. B. bailyi, Woods . . 146

\section{A. Introduction.}

In the description of the Upper Cretaceous fauna of Umkwelane Hill in Zululand,* and in a paper on "Upper Cretaceous Ammonoidea from Pondoland," † reference was made by the writer to a collection of Pondoland Cephalopoda in the British Museum (Natural History). This collection was presented by the Natal Government, through Sir F. Abel, in 1894, $\ddagger$ and thefossils were referred to by Kossmat, $\S$ who examined them in the same year. The late Mr. G. C. Crick described part of this collection, and the writer originally had the intention of revising and completing the MS. The description, apparently, was begun some time after Kossmat's visit, but before the publication of Mr. Woods's "Cretaceous Fauna of Pondoland "; $\|$ for, e.g., a specimen of Baculites had been given a new name by Crick, which was altered to B. capensis after the appearance of Woods's

* "Cretaceous Cephalopoda from Zululand," Annals S.A. Mus., xii, pt. vii, No. 16, 1921, p. 223.

$\dagger$ Annals Durban Mus., iii, pt. 2, 1921, p. 39.

‡ See Catal. Natal Contrib. Colon. and Indian Exhib., 1886, p. 44.

$\S$ "Die Bedeut. d. Südind. Kreideform," Jb.K.K.R.A., xliv (1894), Hefte 3 und 4, (1895), pp. 463-4; also Rec. Geol. Survey India, xxviii (1895), pt. 2, p. 42.

II Annals S.A. Mus., iv, pt. vii, No. 12, 1906. 
monograph in 1906. In this paper* Woods also mentioned that Crick hoped to give an account shortly of other Pondoland species of Eulophoceras in the British Museum. The omission of any reference to this genus, proposed by Hyatt in 1903, in the (meaningless) description of the new genus Spheniscoceras as "intermediate between Placenticeras and Sphenodiscus," may indicate that Crick's account was written before 1903; a copy of Hyatt's description of the genus Eulophoceras, however, was added at the end of the MS. by Mr. Crick with the remark, "Not represented in this collection." This the writer is at a loss to understand, considering the close affinity, if not identity, with Eulophoceras, of Crick's genus Spheniscoceras. There are, also, discrepancies, e.g. in the naming of some of the forty-three examples of Mortoniceras, none of which is described in the MS.; but a revision of Crick's MS. has now become unnecessary, for recently Dr. van Hoepen $\dagger$ dealt with many of the forms described by Crick. Accordingly, only a few short extracts from Crick's MS. will here be given, and it is hoped that a general account of the collection and a revision of the generic nomenclature of all the Pondoland Ammonoidea will prove of general interest.

It has been considered advisable to include in the present paper a review of the very important genera Pachydiscus and Parapachydiscus. When describing some of the forms of this group in the "Cretaceous Cephalopoda from Zululand," the writer recognised that Nowak's $\ddagger$ treatment of the genus Pachydiscus, including in that one polyphyletic genus a host of Upper Cretaceous Ammonites of many horizons, was unsatisfactory. Much additional work, however, remained to be done, and even now, in the absence of original material, it is feared that the interpretation of a number of species here referred to must be based merely on the published descriptions and figures. The genotype species, however, or at least representative forms of the various lineages here recognised, are preserved in the British Museum collections. This revision was necessary to enable the writer to place some undescribed new forms, simply labelled "Pachydiscus" by Mr. Crick, but is provisional. The whole family Desmoceratidae, with its trachyostracous descendants, including the "Prionotropidae," will be dealt with in the writer's forthcoming "Monograph of the Gault Ammonites."

After the writer's observations on the Pondoland fauna $\S$ were penned, an account of the stratigraphy of the Umzamba Beds by Mr. W. J. Plows

* Annals S.A. Mus., iv, pt. vii, No. 12, 1906, p. 337.

† "Cretaceous Cephalopoda from Pondoland," Ann. Transv. Mus., viii, 1921, pt. 1.

† " Untersuch. ü. d. Cephalop. d. Ob. Kreide in Polen," pt. iii, Bull. Acad. Sc. Cracovie, Cl. Sc. Math. et Natur., sér. B, Sc. Nat., Juin 1913, pp. 337 and ff.

$\S$ Loc. cit. (Pondoland), pp. 53-56. 
was published.* His paper is of interest, since he records Mortoniceras soutoni from bed 14, which is considerably higher than the basement bed from which the Survey had recorded Pseudophyllites indra. Mr. Plows also points out that this basement bed "is visible for the whole length of exposure at low tide, and is also probably the basement on the right bank of the river." † There should then have been no difficulty in identifying this basement bed. The writer also agrees with Mr. Plows in considering that the fossil contents of these beds could and should be zoned.

Dr. van Hoepen $\ddagger$ is "inclined to regard the Pondoland Beds as of Upper Santonian age." But it should be pointed out that the type of Grossouvre's Gaudryceras rouvillei, $\S$ which species was cited by Dr. van Hoepen, is from an unknown horizon, whereas the very immature specimen of fig. 10, of Upper Santonian age, is more depressed than G. sigcau, v. Hoepen. According to Dr. van Hoepen, there are also differences in the suture-line. Again, the South African species of Schlüteria do not resemble the type of Grossouvre's Desmoceras pyrenaicum. "Lenticeras" jullieni, Pervinquière, is not considered to be related to the Pondoland genus Spheniscoceras, which has priority before Dr. van Hoepen's "Pelecodiscus" ; and "Schloenbachia" fournieri, Grossouvre,\| was on a previous occasion characterised by the writer as being more nearly allied to Gauthiericeras $\uparrow$ of the Coniacian. The Pondoland deposits, or rather the great majority of the Ammonites, may thus still be considered to be of Uppermost Senonian, or more precisely of "Campanian plus Maestrichtian" age, as stated in the writer's previous accounts, where it was pointed out that the five known zones of this Upper Senonian and Maestrichtian probably represent only part of the true succession of horizons. The chances, then, are that a fauna like that of Pondoland, which does not quite agree with, e.g., either the Upper Campanian of Galicia or the Valudayur Group of Southern India, if homogeneous at all, may belong to a hitherto unrecognised intermediate horizon or even horizons. Perhaps, since non-sequences are possible, these horizons are not even consecutive.

The writer's thanks are due to Dr. A. Smith Woodward and to Dr. F. A. Bather of the British Museum, to Mr. Henry Woods of the Sedgwick Museum, Cambridge, to Dr. Rogers, to Dr. Peringuey, and to Mr. E. C. Chubb for assistance in various ways.

* “The Cretaceous Rocks of Pondoland," Annals Durban Mus., iii, pt. 2, pp. 58-66, pl. viii.

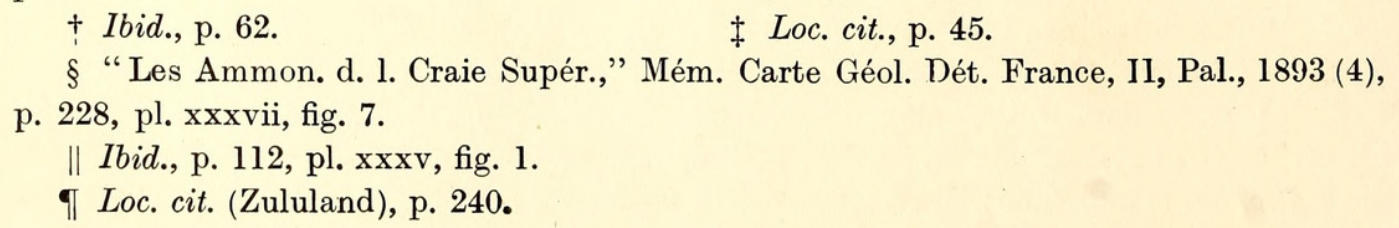

§ “Les Ammon. d. l. Craie Supér.," Mém. Carte Géol. Dét. France, Il, Pal., 1893 (4), p. 228, pl. xxxvii, fig. 7 .

\| Ibid., p. 112, pl. xxxv, fig. 1.

I Loc. cit. (Zululand), p. 240. 


\section{B. DESCRIPTION OF SPECIES.}

\section{Family PHYLLOCERATIDAE.}

Genus Phylloceras, Suess.

1. Phylloceras woodsi, v. Hoepen.

1921. Phylloceras woodsi, v. Hoepen, loc. cit., p. 3, pl. ii, figs. 1-6, text-fig. 1.

1921. Phylloceras nera (Forbes), Spath, Pondoland, p. 40.

The writer examined only one immature example of this species, but Dr. van Hoepen has since shown that the Pondoland form differs in sutureline from the Indian type.

\section{Phylloceras umzambiense, v. Hoepen.}

1920. v. Hoepen, "Descr. of some Cret. Amm. from Pondoland," Ann. Transvaal Mus., vii, pt. ii, p. 142, pl. xxiv, figs. 1-3.

1921. Spath, Pondoland, table, p. 50.

This is a more inflated form than the last, and was compared by the writer to the Patagonian form of Ph. ' nera,' described by Paulcke, and to Ph. pergensi, Grossouvre sp. $=P$. velledae, Sharpe non Michelin sp.

\section{FAMILY LYTOCERATIDAE.}

Genus Gaudryceras, Grossouvre.

3. Gaudryceras tenuilineatum, v. Hoepen.

1921. Gaudryceras tenuilineatum, v. Hoepen, loc. cit., p. 5, pl. ii, figs. 7-9, text-fig. 2.

? 1921. Gaudryceras, sp. juv., Spath, loc. cit., p. 41.

The immature example described by the writer may belong to the finely striated species established by Dr. van Hoepen, but it differs in dimensions. The latter are nearer those of $G$. varicostatum, v. Hoepen, but in this species and in G. cinctum (Crick MS.) the striation is coarser.

\section{Gaudryceras varicostatum, v. Hoepen.}

1921. Gaudryceras varicostatum, v. Hoepen, loc. cit., p. 7, pl. ii, figs. 10-12, text-figs. 3-4.

1921. Gaudryceras kayei (Forbes), Spath, loc. cit., table to p. 50.

Dr. van Hoepen may be right in including in $G$. varicostatum the $A$. kayei recorded by Griesbach and figured by Woods. The writer compared this 
species to G. pulchrum, Crick, which has the dimensions of van Hoepen's species, but six labial ridges on the outer whorl.

5. Gaudryceras cinctum (Crick MS.), Spath.

(Plate IX, figs. $3 a, b$.)

1921. Spath, Pondoland, loc. cit., pp. 41-2, and table to p. 50.

This species is represented by a single, well-preserved example (No. C 19415), the dimensions of which are 64.5--40-37-34. Mr. Crick's long description of this form is not given, since the species is extremely close to G. varicostatum, v. Hoepen, and may only be the adult of the latter form. G. varicostatum, however, at a smaller diameter, has $\mathrm{H}>\mathrm{Th}$, and has a larger umbilicus. Crick also had compared his species to Griesbach's A. kayei, Forbes. The whorls of G. cinctum, however, are fewer, and the striation is coarser than in the typical Pondicherry examples of G. kayei in the British Museum.

The writer compared this species to G. mite (Hauer), which is very close, but according to de Grossouvre * belongs to the Santonian.

G. varagurense, Kossmat, which had been thought by Crick to be very close to $G$. cinctum, has much finer ornamentation, and a different ribcurve. G. varagurense, var. patagonica, Paulcke, $\dagger$ is comparatively involute.

\section{Gaudryceras amapondense, v. Hoepen.}

1920. v. Hoepen, loc. cit., p. 143, pl. xxiv, figs. 4 and 5.

1921. Spath, loc. cit., table to p. 50.

The holotype of this species, compared by the writer to G. colloti, Grossouvre, and G. glaneggense (Redtenbacher), has its inner whorls too badly preserved for exact determination, but is more involute than $G$. cinctum. Its ornament is also far less regular.

\section{Gaudryceras sigcau, v. Hoepen.}

1921. Loc. cit., p 9, pl. ii, figs. 13-16, text-fig. 5.

This species is based on immature specimens, compressed already at a very early stage, and thus different from any of the known Pondoland forms of Gaudryceras.

* Craie Supér., 1894, pp. 227-8.

† “Ceph. d. Ob. Kreide S. Patagon.," Ber. Naturf. Ges. Freiburg i. B., xv, 1907. p. 6, pl. xvii (viii), figs. 1-2. 


\section{Genus Tetragonites, Kossmat.}

8. Tetragonites superstes, v. Hoepen.

$$
\text { (Plate VI, fig. 6.) }
$$

1921. Tetragonites superstes, v. Hoepen, loc. cit., p. 10, pl. ii, figs. 17-20, text-fig. 6.

1921. Tetragonites cf. epigonum (Kossmat), Crick, in Spath, loc. cit., p. 42.

The figured example, clearly belonging to v. Hoepen's species, is the specimen (No. C 19416) referred to by the writer, but the Tetragonites (?) sp. ind. described in the same place may be a young (and crushed) Pseudophyllites.

\section{Tetragonites nuperus, v. Hoepen.}

1921. Tetragonites nuperus, v. Hoepen, loc. cit., p. 13, pl. iii, figs. 3 and 4, text-fig. 8 .

? 1921. Tetragonites aff. cala (Forbes), Spath, loc. cit., p. 43.

This species differs from Forbes's type in having greater inclusion and constrictions that describe a slightly different curve. The example compared by the writer to the Valudayur specimens in the British Museum may be still closer to Forbes's species, but is more evolute than the example figured by Woods.* The suture-lines of all these forms of Tetragonites are very similar.

\section{Genus Pseudophyllites, Kossmat. \\ 10. Pseudophyllites indra, Forbes sp.}

1906. Pseudophyllites indra (Forbes), Woods, loc. cit., p. 334, pl. xli, fig. 6 .

? 1920. Tetragonites teres, van Hoepen, "Descr. of some Cret. Amm. from Pondoland," Ann. Transvaal Mus., vii, pt. ii, p. 144, pl. xxv, figs. 1 and 2.

1921. Tetragonites (?) sp. ind., Spath, loc. cit., p. 42, pl. vii, fig. 3.

1921. Pseudophyllites indra (Forbes), ib., table to p. 50.

? 1921. Tetragonites virgulatus, v. Hoepen, loc. cit., p. 11, pl. iii, figs. 1 and 2 , text-fig. 7 .

This well-known and widely distributed species is represented in the present collection by three specimens (No. C 19417-9), the largest of which Crick described as being, " as Kossmat has already stated, by far the largest fig. 7 . 
example of the species yet known. It is $290 \mathrm{~mm}$. in diameter (nearly $11 \frac{1}{2}$ inches), and its greatest thickness $148 \mathrm{~mm}$; there are indications of the former existence of at least another half whorl, so that the specimen when complete must have attained a very large size. The specimen is entirely septate, and the portion of the whorl that is missing was probably occupied by the body-chamber."

"Another example (No. C 19418) is only $70 \mathrm{~mm}$. in diameter, but is without doubt referable to the same species."

"A third example (No. C 19419), in a somewhat harder and darker sandstone, appears to be referable to this species. At first sight it seems to be more compressed, and to have less rapidly increasing whorls and a steeper umbilical wall than Pseud. indra, but these differences may in part be due to the imperfection of the anterior part of the outer whorl. Portions of the mouth-border are preserved on each side, and these show that the aperture was very oblique, the ventral (peripheral) portion being projected considerably forward. The body-chamber is seen to occupy rather more than one half of the outer whorl."

\section{Family DESMOCERATIDAE, Zittel.}

The genera Pachydiscus, Parapachydiscus, Parapuzosia, Kossmaticeras, and the many allied developments discussed in the following pages can all be derived from Desmoceratid stocks that persisted during the Upper Cretaceous, and the unmodified types of which, owing to lack of exact information, are at present included in the genus Puzosia, Bayle, though the latter really should be restricted to the Upper Albian-Cenomanian planulata-group. Some of these Puzosid developments will be referred to below, under Puzosinae, a convenient but polyphyletic assemblage of successive waves of modified Phylloceratids; but with regard to the Pachydiscinae, a sub-family that includes a number of developments of Puzosinae, the genus

\section{Pachydiscus, Zittel,}

is here taken to include only the group of $P$. peramplus, Mantell sp., as suggested by Kilian and Reboul * after Pervinquière and other writers. Other species of this genus are: P. prosperianus, d'Orbigny sp., P. lewesiensis, Mantell non Sharpe sp., P. catinus, Mantell sp., P. rhodanicus, Roman and Mazeran, P. juvencus, Laube and Bruder sp., P. vaju, Stoliczka sp., and probably P. seppenradensis, Landois. A. undatus, J. de C. Sowerby, $\dagger$

* "Les Céphalop. Néocrét. des Iles Seymour et Snow-Hill," Wiss. Ergebn. Schwed. Südpol. Exp., iii, pt. vi, 1909, p. 41.

† Min. Conch., vi, 1827, p. 134, pl. dlxix, fig. 2, B.M., No. $43940 a$. 
which Sharpe * long since had considered to be " better omitted from our lists," may be a crushed Pachydiscus of this group. "Pachydiscus" vectensis, Sharpe sp., like Sowerby's $A$. cinctus, apparently is based on a malformation. Whether the supposed Turonian Pachydiscus laevicaniculatus (Roemer), Lasswitz, $\dagger$ belongs to this restricted Pachydiscus seems doubtful.

The simple suture-line, with its small external saddle, and the specialisation in size mark this genus as a very distinct assemblage of closely allied forms. Nowak derived it from Uhligella, but strong costation appears repeatedly in Desmoceratidae during the Cretaceous, not only in the Aptian, to which formation the true Uhligella is restricted, though probably the Pachydiscus ancestor is nearly related to such a Puzosid as that figured by Pervinquière as Pachydiscus sp.ł and quoted by Nowak. This stock continued into the Senonian, and gave rise, in addition to Kossmaticeras, to at least two more developments, resembling the young Pachydiscus peramplus, namely, Nowakites, mentioned below, which attaches itself to such forms as 'Puzosia' le marchandi, Grossouvre,\| of the Lower Senonian, and the later Canadoceras, which is a close ally of the Puzosid group here separated as Kitchinites.

\section{Pseudojacobites, gen. nov.,}

is here proposed for those Turonian forms that, like $P$. farmeryi, Crick sp. (genotype: "Two Cephalopods from the Chalk of Lincolnshire," Geol. Mag., N.S., decade v, vol. vii, 1910, p. 345, pl. xxvii, figs. 1, 2, B.M., No. C 12220), develop multituberculation, and attach themselves to the true Pachydiscus, possibly via such forms as 'Pachydiscus' anapadensis, Kossmat sp. The exact relations, however, of this latter form, as of ' $P$.' rotalinus, Stoliczka sp., which Kossmat thought might come from the same beds, and which is classed as Cenomanian by Nowak, $\uparrow$ are not clear. Boule, Lemoine and Thévenin,** and Kilian and Reboul †† record it from the Upper Senonian, and the last-named authors put it in the genus Jacobites, but this is a late Campanian development of the sparsicosta-group of Kossmaticeras; and the inner whorls of 'Pachydiscus' rotalinus do not suggest affinity with

* "The Fossil Moll. Chalk of England," II, Cephalopoda, iii, 1857, p. 46.

$\dagger$ " Kreide Amm. v. Texas," Geol. und Pal. Abh., N.F., vi, 1904, p. 16, pl. iii, fig. 2.

¥ “Amm. du Crét. Algér.," Mém. Soc. Géol. France, Pal. xvii, No. 42, 1910, p. 37, pl. iii, figs. 1-3.

§ Loc. cit., p. 347.

|l "Les Ammon. d. l. Craie Supér.," Mém. Carte Géol. Détail. d. l. France : II, Paléont., 1894, p. 173, p]. xxii, fig. 5.

ๆ Loc. cit., 1913, p. 347.

** “Pal. de Madagascar : III, Céph. Crét. d. Envir. de Diego-Suarez,” Ann. de Pal., i, fasc. 4 (1906), pl. vi, fig. 5, and pl. vii, fig. 1.

†† Loc. cit., 1909, pp. 37 and 52. 
this stock. On the other hand, 'Pachydiscus' rotalinoides, Yabe, ${ }^{*}$ from the Senonian Toyayo series, which may include any Senonian horizons below the Parapachydiscus-beds of the Hokkaido, and also, apparently, not a Jacobites, may possibly belong to the genus Menuites, described below.

\section{Parapachydiscus, Hyatt,}

was proposed for A. gollevillensis, d'Orbigny, which is very close to Parap. crishna and to Parap. egertoni, Forbes sp., the latter again a very near ally of the European Parap. neubergicus, Hauer sp., Parap. perfidus, Grossouvre sp., and Parap. jacquoti, Seunes sp. Kossmat's Indian "P. gollevillensis," † here renamed Parap. compressus, n.n., is different from the European type as figured by d'Orbigny and Seunes. $\ddagger$ A specimen in the British Museum from the Baculite Limestone of Valognes, Manche (No. 50135), represents a new form (Parap. valognensis, nov.), with a whorl-thickness of 30 per cent., more closely costate and flatter even than Grossouvre's fig. 9 of plate xxxi. Sharpe's A. gollevillensis $§$ represents a more coarsely ornamented type, and the new name Parap. sharpei is here proposed for it. A series of Irish specimens in the British Museum includes a further new form, Parap. hibernicus, nov. (type No. C 15126), which differs from Parap. oldhami, Sharpe sp., in the coarseness of its ornament and from Parap. sharpei in having the whorl-section more rounded and the inner whorls continuously costate. Other varieties of Parap. oldhami are more finely costate than the type or Grossouvre's form,\| e.g. specimen No. C 14830.

A. soma, Forbes, which is not identical with the more inflated A. ganesa, Forbes, as Stoliczka and Kossmat had thought, belongs to this group of the genus Parapachydiscus, also P. haldemensis, Schlüter sp. and, probably, the compressed forms figured by Nowak on plate xl, but the group is not equivalent to Nowak's egertonianus-series.

Apart from these compressed forms, which may tend to differentiate the ornamentation on the ventro-lateral edges, Parapachydiscus also includes many forms that develop inflated whorls and that are closely connected with the previous group by such forms as Parapachydiscus ganesa (Forbes), $P$. cricki (Kossmat), and P. complexus (Meek). The numerous species grouping themselves round Parap. colligatus (Binkhorst) and P. deccanensis (Stoliczka) belong to this division of Parapachydiscus, including the three forms

* "Notes on some Cret. Foss. from Anaga, etc.," Science Rep., Tôhoku Imper. Univers., 2nd ser. (Geol.), iv, No. 1, 1915, p. 21, pl. ii, figs. 5 and 6.

† “Unters. S. Ind. Kreideform.," iii, 1898, p. 97 (162), pl. xxi (xv), fig. 1.

† "Contrib. Céph. Crét. Supér. France," Mém. Soc. Géol. France, Pal., No. 2, 1891, pl. 5, fig. 1 only.

§ Loc. cit. (iii, 1857), p. 48, pl. xxii, fig. 2.

|| Loc. cit., 1894, pl. xxii, fig. 1. 
described by the writer from Zululand, and the Parapachydiscus aff. ootacodensis (Stoliczka) described below. P. neubergicus, var. stallauensis, Imkeller,* better renamed Parapachydiscus stallauensis, apparently belongs to this second division rather than the first.

Within this comprehensive genus Parapachydiscus several lineages, no doubt, could be separated, perhaps by means of the suture-line, but with the data available at present such subdivisions appear to the writer to be artificial, and he would class as Parapachydiscus, e.g., both Pachydiscus koluturensis (Stoliczka), Yabe and Shimizu, $\dagger$ and Parapachydiscus fascicostatum, Yabe sp.‡

A bituberculate development, derived from the more globose forms of the genus Parapachydiscus, leads to $A$. menu, Forbes, with scaphitoid coiling; this development is here separated as

\section{Menuites, gen. nov.}

(genotype: A. menu, Forbes, "Report on the Fossil Invertebrata from Southern India, collected by Mr. Kaye and Mr. Cunliffe," Trans. Geol. Soc., ser. ii, vol. vii, 1845, p. 111, pl. x, fig. 1, B.M., Geol. Soc. Coll., No. 10482). $M$. sturi, Redtenbacher sp., and $M$. portlocki, Sharpe sp., well figured by Griepenkerl $\S$ and Wollemann,\| and $M$. selbiensis, Pervinquière sp., belong to this stock.

The original figure of Schlüter's $A$. proteus suggests that $A$. auritocostatus, Schlüter, and 'Pachydiscus' ambiguus, de Grossouvre, represent compressed forms of this genus Menuites.

The possibility of certain Scaphitids of the Campanian (Hoploscaphites, Acanthoscaphites ?) having been derived from the present group of Desmoceratids has already been pointed out by the writer. Other late Senonian Scaphitids, however, at present included in these genera, are derived from Hoplitoplacenticeras (= group of 'Hoplites' vari).

The Campanian and Maestrichtian genus Parapachydiscus, as here understood, is not a direct descendant of the Turonian Pachydiscus. It has already been mentioned that in the Lower Senonian there is a group of forms, namely,

* "Die Kreidebild. u. ihre Fauna a. Stallauer Eck u. Enzenauer Kopf bei Tölz," Palaeontographica, 48 (1901), p. 57, pl. iii, fig. 5 .

$\dagger$ "Notes on some Cret. Amm. from Japan and California," Science Reports, Tôhoku Imper. Univ., 2nd ser. (Geol.), v, No. 3, 1921, p. 55, pl. viii, fig. 3.

¥ "Notes on some Cret. Amm. from Japan and California," Science Reports, Tôhoku Imper. Univ., 2nd ser. (Geol.), v, No. 3, 1921, p. 57, pl. viii, fig. 5, and pl. ix, figs. 2-5.

$\S$ “Die Verstein. d. Senon. Kreide v. Königslutter, etc.," Pal. Abh., iv, 1889, p. 99, (401), pl. xii, fig. 2 .

|| "Fauna d. Lüneburger Kreide," Abh. Preuss. Geol. Landesanst., N.F., Heft 37 1902, p. 104, pl. vi, figs. 2-3. 
Nowakites, gen. nov.

(genotype: N. carezi, de Grossouvre sp., loc. cit., 1894, p. 190, pl. xxv, fig. 3), attaching itself to such contemporaneous (Coniacian) forms as 'Puzosia' le marchandi, Grossouvre. Nowakites draschei, Redtenbacher sp., N. yokoyamai, Jimbo sp., N. canali, N. linderi, Grossouvre sp., and N. paillettianus, d'Orbigny sp., probably all belong to this genus, the last apparently entirely different from the Texas $A$. flaccidicosta, Römer, with which Thomas and Peron and Nowak (loc. cit., p. 354) had identified it.

Nowakites savini, Grossouvre sp., represents a lateral offshoot. The forms also bear some resemblance to certain tuberculate Madrasites, Pseudokossmaticeras, and Canadoceras, all of which, however, are of uppermost Senonian age. On the other hand, the Lower Utatur

Holcodiscoides, gen. nov.

(genotype: A. cliveanus, Stoliczka, "Foss. Ceph. Cret. Rocks S. India," 1865 , p. 157 , pl. lxxvii, fig. 3), which also includes $H$. moraviatoorensis, papillatus, and paravati, Stoliczka sp., and which has wrongly been included in Kossmaticeras, is not directly related either to Nowakites or to Madrasites.

For 'Sonneratia' janeti, Grossouvre, which forms a separate development, allied to Nowakites,

Pachydiscoides, gen. nov.

(loc. cit., 1894, p. 145, pl. xxii, fig. 4) is proposed. ? Pachydiscoides pervinquierei, n.n.=P. n. sp. cf. $P$. janeti, Pervinquière non Grossouvre, ${ }^{*}$ probably belongs to the same stock.

From the Coniacian stock, here separated as Nowakites, forms with increasingly strong ornamentation, like Redtenbacher's $A$. isculensis, result, for which the genus

Eupachydiscus, gen. nov.

(genotype: ' $P$.' isculensis (Redtenbacher), Grossouvre, pl. xxvi, fig. $1 a, b$ only), is proposed. Nowakites linderi (Grossouvre, pl. xxiv, fig. 4), one of the largest species of that genus, already foreshadows the present development; on the other hand, Eup. levyi (Grossouvre) and Eup. grossouvrei (Kossmat) are transitional to the later and much more abundant Parapachydiscus, in which tuberculation seems to begin already in the smooth initial stage. Eup. jeani (Grossouvre) is another species, and a Japanese example, studied by the writer, apparently allied to 'Pachydiscus' haradai and $P$. teshionensis, Jimbo, may belong to the same stock.

* “Et. de Pal. Tunis., I, Céph. d. Ter. Second.” (1907), p. 174, pl. vii, fig. 11. 
The genus

Canadoceras, gen. nov.

(genotype: A. newberryanus, Meek [Trans. Albany Inst., iv, 1857, p. 47, "Descr. and Illustr. Foss. Vancouver's and Sucia Islands, etc."; Bull. U.S. Geol. and Geogr. Survey Terr., ii, 1876, p. 367, pl. iv, fig. 3], B.M. Geol. Soc. Coll., specimen figured Plate VII, fig. 5, Plate VIII, fig. 4), of the Upper Chico Formation, is allied to the Puzosid development Kitchinites, referred to below under Puzosinae, i.e. to the group of "Holcodiscus" pondicherryanus, Kossmat, which persists in the Campanian, together with the true Kossmaticeras and its allies. A. newberryanus, Gabb non Meek* =" Pachydiscus" henleyensis, Anderson, is probably a Parapachydiscus of the colligatus-group, though Anderson, $\dagger$ perhaps wrongly, puts it as of Lower Chico age, and confuses with "Pachydiscus" even Horsetown species of Pleuropachydiscus ("Pachydiscus" sacramenticus) and of Desmoceras s.s.=Latidorsella, Jacob ("P." merriami).

A. fraternus, Meek, and A. suciensis, Gabb non Meek, $\ddagger$ belong to Canadoceras, as does a closely allied species in the British Museum. The true A. suciensis, Meek, or, at least, smooth Vancouver examples in the British Museum, are more doubtfully included here; "Pachydiscus" neevesi, Whiteaves, is probably a Grossouvrites.

Some of the more inflated forms, like C. multisulcatum, binodatum, and perplicatum, Whiteaves sp., though having inner whorls of the newberryanus-type, resemble some forms of the other genera here separated; e.g. there may be a tendency to acquire the oblique costation of Kossmaticeras, like K. pachystoma, Kossmat sp., or of Kitchinites japonicus, n.n.=Desmoceras gaudama, Yokoyama non Forbes, $\S$ testifying to the Puzosid ancestry of the pachydiscoid 'Kossmaticeras' here named Canadoceras.

The smoother Canadoceras of the suciensis-group above mentioned resemble a somewhat parallel development, provisionally left in the genus Parapachydiscus, and including slowly or quickly coiled (globose) forms, retaining the varices or constrictions of the Desmoceratid ancestors; e.g. the Southern Patagonian P. hauthali, P. steinmanni, and P. patagonicus, Paulcke sp., probably also the Japanese 'Pachydiscus' naumanni, Yokoyama. $P$. antecursor, v. Hoepen sp., and P. umtafunensis (Crick MS.), Spath, connect this group with the true Parapachydiscus, and after a short hauthalistage develop ornamentation foreshadowing that of the cricki-group of

* Pal. Calif., i (1864), p. 61, pl. xxvii, figs. 199, 199b, $c$; pl. xxviii, fig. 199a.

$\dagger$ "Cret. Depos. Pacif. Coast," Proc. Calif. Acad. Sc. (3) Geol., ii, (1902), p. 104 (Wrongly quoted as A. suciaensis.)

$\ddagger$ Loc. cit., ii (1869), p. 133, pl. xxi, figs. 11, 11a, b.

$\S$ “Verstein. a. d. Japan. Kreide," Pal., xxxvi (1890), p. 184, pl. xix, fig. 5. 
Parapachydiscus. P. amarus, Paulcke sp., is a transitional species from Kitchinites or Kossmaticeras.

The young of 'Pachydiscus' conduciensis, Choffat, * somewhat resembles P. umtafunensis, and Choffat's gigantic species may have to be considered as a special offshoot of this group of Parapachydiscus. The new genus

\section{Lytodiscoides, gen. nov.}

(genotype: Pachydiscus conduciensis, Choffat, loc. cit., p. 18, pls. ii-v and frontispiece), is proposed for this development. The ornamentation here, though also increasing in strength, is of quite a special type.

As regards the sub-family Kossmaticeratince, the genus Madrasites, Kilian and Reboul, is a descendant of the true Kossmaticeras (theobaldianus-group), and Gunnarites and Grossouvrites are closely allied genera, but Seymourites and Grahamites are still doubtful, and at any rate cannot be regarded as subgenera of Kossmaticeras. A late Campanian type that, unlike Madrasites, does not tend to involution, but leads, via forms of the group of $A$. brandti and $A$. düreri, Redtenbacher, to Brahmaites, requires a new name, and

\section{Pseudokossmaticeras, gen. nov.}

(genotype: A. pacificus, Stoliczka, loc. cit., 1865, p. 160, pl. lxxvii, fig. 9), is here proposed. Most of the European "Kossmaticeras" belong to this stock.

\section{Sub-FAmily PUZOSINAE.}

Nowak introduced his genus Parapuzosia for Ammonites of the 'denisoni'type, and he erroneously thought that they could be traced from the Cenomanian to the uppermost Cretaceous. It might, of course, be held that $A$. denisonianus, Stoliczka, is thus the genotype; but this species is not cogenerjc with Parapuzosia daubreei (Grossouvre), the only species described and figured by Nowak, so that the writer selected this Santonian form as the type of the genus Parapuzosia, which also should include Parap. leptophylla and P. (?) icenica, Sharpe sp., P. corbarica, Grossouvre sp., P. gaudama, Forbes sp., P. indopacifica, Kossmat sp. and P. stobaei, Nilsson sp., the latter possibly transitional to Parapachydiscus. $\dagger$ The unornamented A. griffithii, Sharpe, may be close to the last species, as de Grossouvre thought; for Sharpe's drawing of its suture-line is obviously quite sketchy.

* "Contrib. Connaiss. Géol. Col. Portug. d’Afr. : I, Le Crét. de Conducia," Comm. Serv. Géol. Portug., 1903, p. 18, pls. ii-v and frontispiece.

$\dagger$ This form was considered to be a Parapachydiscus in Cret. Ceph. fr. Zululand, 1921, p. 225 . 
Parapuzosia has the course of the radial line and the constrictions of the strongly projected subplanulata-type different from the straight ornamentation of the Campanian

Kitchinites, gen. nov.

(genotype: Holcodiscus pondicherryanus, Kossmat, loc. cit., 1897, p. 40 (147), pl. vi (xvii), fig. 6; British Museum, Geol. Soc. Coll.). This also includes K.japonicus, n.n. (=Desmoceras gaudama, Yokoyama non Forbes), and a South American form before the writer, near to $K$. darwini (Philippi in Steinmann). The genus is very close to the stock from which also originated Kossmaticeratinae (namely, Kossmaticeras, Madrasites, Gunnarites, Jacobites, Pseudokossmaticeras, Brahmaites), but not the isolated Holcodiscoides, which is a much earlier offshoot from Puzosinae. 'Puzosia' ishakawai, Jimbo, is probably a young Kitchinites, hardly distinguishable from the ancestral Parapuzosia.

That the genera Parapuzosia and Kitchinites, which continue the true Puzosid type into the Senonian, are not derivatives of the Cenomanian A. denisonianus, is clear; for the latter already develops a pachydiscoid stage, and

\section{Pachydesmoceras, gen. nov.}

(type: A. denisonianus (Stoliczka), Kossmat, loc. cit., 1898, p. 121 (186), pl. xv, figs. $5 a, b)$, is here proposed for this form. It is probably closely related to the contemporary Puzosia of the typical planulata-group rather than to the Aptian Uhligella, and the Cenomanian Holcodiscoides is a close ally. But in the Turonian, true Puzosids still persist and give rise to at least two developments, one specialising in size (Austiniceras) and the other in crenulation of the periphery (Tragodesmoceras). The genus

\section{Austiniceras, gen. nov.}

(genotype : A. austeni, Sharpe, loc. cit., ii, 1855, p. 28, pl. xii, figs. $1 a$ and $b$, non 2, B.M., No. C 3382), has inner whorls of the type of $A$. dibleyi, n.n.(= A. austeni, Sharpe, p.p. pl. xii, fig. 2 only, holotype, B.M., No. C 13912, Dibley Coll. from Holaster subglobosus zone), which is more involute than the type species, and on the outer whorl develops costation of a different type, foreshadowing that of the later Parapuzosia. The gigantic A. mobergi, A. poctai, Grossouvre, and A. montis-albi, Laube and Bruder, belong to this genus Austiniceras.

\section{Tragodesmoceras, gen. nov.}

(genotype: Desmoceras clypealoides, Leonhard, “D. Fauna d. Kreidef. i. Oberschles.," Pal., vol. 44 (1897), p. 57, pl. vi, fig. 2), is proposed for a group 
of desmoceratid forms sometimes included in Muniericeras. This was referred to by the writer on a previous occasion, ${ }^{*}$ and forms the lineage leading from the Turonian Tr. clypealoides (Leonhard), Tr. mülleri (Grossouvre), and Tr. hernensis (Schlüter) to the Lower Senonian Tr. clypeale (Schlüter). This lineage is of interest on account of the probable derivation therefrom of keeled forms.

Neither of the genera Austiniceras and Tragodesmoceras is the direct ancestor of Parapuzosia; for in the Turonian forms occur (cf. Puzosia curvatisulcata, Chatwin and Withers, and $P$. marlowense, Noble) which are still of the regular Puzosia type. The latter was compared to Desmoceras pyrenaicum, Grossouvre, which, however, is a Schlüteria; the former (P. curvatisulcata), with a very complex suture-line (B.M., No. C 12229), may be an Austiniceras, and resembles A.? gaudemarisi, Roman and Mazeran sp., but is too fragmentary for exact determination.

\section{Genus Parapuzosia, Nowak.}

11. Parapuzosia haughtoni, sp. nov.

(Plate VIII, fig. 1.)

? 1921. Parapuzosia, sp. nov.? ind., Spath, loc. cit. (Zululand), p. 224, pl. xix, fig. 2 ; pl. xx, figs. $1,1 a$; pl. xxiv, fig. 3 .

The large fragment (No. C 19439) on which this description is based, labelled "Pachydiscus sp." by Crick, was referred to $\dagger$ as probably a Parapachydiscus of the colligatus-supremus type on account of its resemblance in smoothness and section of the outer whorl and suture-line to those of the example here described as Parapachydiscus aff. ootacodensis (Stoliczka). On preparation of the umbilical and dorsal portions of the fragment, however, the ornamentation of the inner whorl was revealed, showing the primary and secondary ribs characteristic of Parapuzosia daubreei.

At a whorl-height of $260 \mathrm{~mm}$., the thickness was probably not more than $180 \mathrm{~mm}$. (not $200 \mathrm{~mm}$., as stated in the footnote on p. 229 , loc. cit.). The whorl-section thus agrees with that given by the writer for the Zululand form (loc. cit., pl. xx, fig. 1a), and is not so compressed as that of P. daubreei as figured by Nowak. $\ddagger$ The umbilical wall is higher, and the whorl is thicker at the umbilical border in the South African form; on the other hand, there is no definite umbilical edge, as noted of $P$. daubreei by Grossouvre, but the sides are gradually rounded off into the umbilicus, as illustrated by

* Loc. cit. (Zululand, 1921), p. 237.

$\dagger$ Loc. cit. (Zululand, 1921), p. 229.

¥ "Untersuch. ü. d. Ceph. d. Ob. Kreide i. Polen." : III, Bull. Acad. Sc. Cracovie, Classe Sc. Math. and Nat., ser. B, June 1913, fig. 32, pl. xliii. 
Nowak and by the writer for the Zululand example. Since the description of the latter was based only on the photographs and plaster cast of the dorsal area, it is uncertain, of course, whether it belongs to the present species. A comparison of the casts of the dorsal areas of the two forms, however, shows that at any rate the inner whorls, with the typical strongly projected Parapuzosia ribbing, are closely similar.

Genus Schlüteria, Grossouvre em.

12. Schlüteria simplex, v. Hoepen sp.

1921. Desmoceras simplex, v. Hoepen, loc. cit., p. 19, pl. iii, figs. 11-16, text-fig. 10.

1921. Schlüteria woodsi, Spath, Pondoland, p. 45, pl. vii, fig. 1.

The writer does not lay stress on minute differences in the convexity of the sides, proved to be due to sexual dimorphism in the recent Nautilus. The dimensions of the two forms, quoted in the synonymy, agree, but whereas Dr. van Hoepen had comparatively small examples, the specimen figured by the writer measured $85 \mathrm{~mm}$. in diameter.

\section{Schlüteria crassa, v. Hoepen sp.}

1906. Phylloceras sp., Woods, loc. cit., p. 332, pl. xli, fig. 5.

1921. Desmoceras crassum, v. Hoepen, loc. cit., p. 20, pl. iv, figs. 3-4, text-fig. 11.

This form shows more inflation than the last species. It is interesting to note the complexity of its suture-line at a small diameter as compared with that of the Santonian form figured by Grossouvre.*

\section{Genus Hauericeras, Grossouvre.}

14. Hauericeras gardeni, Baily sp.

1921. Spath, Zululand, loc. cit., p. 238, text-fig. A.

1921. v. Hoepen, loc. cit., p. 27, text-fig. 15.

1921. Spath, Pondoland, loc. cit., p. 50 (table).

To the writer's notes on this form in the above-mentioned paper it is only necessary to add that the late G. C. Crick took measurements of 20 out of the 37 examples in the present collection, and the mean of these measurements is :

whorl-height $=35$ per cent. of the diameter.

whorl-thickness $=19 \quad,, \quad, \quad$, umbilicus $=39 \quad,, \quad$,

* Loc. cit., 1894, pl. xxxvii, fig. 9 (as Desmoceras pyrenaicum). 
The percentages given by $v$. Hoepen are $\cdot 34-\cdot 17-\cdot 40$ for an example of $120 \mathrm{~mm}$. diameter. The specimens range from $60 \mathrm{~mm}$. (B.M., No. C 18521) to $145 \mathrm{~mm}$. (C 18516) in diameter, and the relatively thickest form (C 18518) has a narrow umbilicus (dimensions : $130-\cdot 34-\cdot 215-\cdot 40$ ), whereas the thinnest form (C 18517) has a wide umbilicus (dimensions : $138-\cdot 30-\cdot 16$ --46). This, as Mr. Crick observes, is contrary to the general rule given by Grossouvre,* namely, that in the same specific type individuals with a narrow umbilicus show a corresponding compression of the whorls.

The transverse section of an example $106.5 \mathrm{~mm}$. in diameter (B.M., No. C 18520), very close to the type-specimen, allowed of measurements being taken at different stages, and Crick's figures are here appended :

\begin{tabular}{|c|c|c|c|c|c|c|c|}
\hline Diameter of & $106 \cdot 5(1$ & $78 \cdot 0$ & ) $55 \cdot 0$ & $38 \cdot 0 \quad(1$ & $26 \cdot 0 \quad(1$ & $18 \cdot 5 \quad(1$ & $12 \cdot 75(1$ \\
\hline $\begin{array}{l}\text { Height of } \\
\text { outer whorl }\end{array}$ & $(0 \cdot 352)$ & $(0 \cdot 378)$ & $20 \cdot 75(0 \cdot 377)$ & $14 \cdot 75(0 \cdot 388)$ & $10 \cdot 0 \quad(0 \cdot 384)$ & $6.5 \quad(0.351)$ & $4.5 \quad(0.352)$ \\
\hline $\begin{array}{l}\text { Thickness of } \\
\text { outer whorl }\end{array}$ & $(0 \cdot 201)$ & $(0 \cdot 211)$ & $11 \cdot 5 \quad(0 \cdot 20)$ & $8 \cdot 25(0 \cdot 218)$ & $5 \cdot 75(0 \cdot 221)$ & $3.5 \quad(0 \cdot 189)$ & $3.5 \quad(0 \cdot 274)$ \\
\hline $\begin{array}{c}\text { Width of } \\
\text { umbilicus }\end{array}$ & $(0 \cdot 389)$ & $28 \cdot 25(0 \cdot 362)$ & $(0 \cdot 354)$ & $13.5 \quad(0 \cdot 355)$ & $10 \cdot 0 \quad(0 \cdot 384)$ & $6 \cdot 75(0 \cdot 364)$ & $4.5 \quad(0 \cdot 352)$ \\
\hline
\end{tabular}

The same transverse section shows that at a diameter of $13 \mathrm{~mm}$. there is no keel, whereas at $18 \mathrm{~mm}$. it first begins to be indicated very feebly. Up to a diameter of $50 \mathrm{~mm}$., the constrictions, also, are biconvex, like those of H. fayoli, Grossouvre, or of Forbes's small types of $H$. rembda (=A. durga). The course of the constrictions, if it remains biconvex in larger examples of H. rembda, as drawn by Stoliczka, $\uparrow$ may serve as a distinction between the two species, as, e.g., Pervinquière $\ddagger$ had thought; for the larger whorls of $H$. gardeni have semicircular constrictions, sloping forwards towards the umbilical suture as much as the outer half is projected forwards towards the keel. In several examples the apex of this semicircular curve is slightly flattened; in others there may be a small indentation in the semicircle, either near the umbilical edge (No. C 18540) or nearer the periphery (C 18537), suggestive of the original biconvexity, and in the transitional stage the course of the constrictions would be as described for $H$. sulcatus by Kner and Nowak.§

The last example has the periphery of the cast (but not that of the test) still rounded at a diameter of $110 \mathrm{~mm}$., as in Baily's larger specimen (No. 11371, Geol. Soc. Coll.). Another example (C 18522) has lateral grooves

* Loc. cit. (1894), p. 8.

$\dagger$ Loc. cit. (1864), pl. xxxiii, fig. 5 .

$\ddagger$ Loc. cit. (1907), p. 169.

$\S$ Kner, "Verstein. d. Kreidemerg. v. Lemberg.," Naturw. Abh., iii (1850), 2, p. 8, pl. i, fig. 3; and Nowak, loc. cit., p. 371, pl. xli, fig. 12, pl. xlv, figs. 44-45. 
accompanying the keel (of test only) at $90 \mathrm{~mm}$. diameter, and specimen No. C 18535 has a very strong keel, just beginning to become undercut, as in $H$. rembda, at about $110 \mathrm{~mm}$., set on the far less acute periphery of the cast. Forbes's type of $H$. rembda, on the other hand, shows the acute periphery of the cast, and the peculiar polygonal keel already at $30 \mathrm{~mm}$. diameter. This keel is a more distinct characteristic of $H$. rembda than the biconvex constrictions.

The suture-line of $H$.gardeni (Baily's paratype 11371) differs from that of $H$. sulcatum, as figured by Nowak, in the very regular decrease of the three auxiliary saddles down to the umbilical lobe, a character shown also in some Japanese examples before the writer (Geol. Soc. Coll.). In the latter, however, the periphery is more compressed than in $H$. gardeni typus, or in $H$. fayoli, which latter species they resemble in their constrictions.

H. gardeni, in the present collection, is associated, in the same handspecimens, with Mortoniceras, Pseudoschloenbachia, and Spheniscoceras.

\section{Hauericeras rembda (Forbes).}

1921. v. Hoepen, loc. cit., p. 28.

1921. Spath, loc. cit., table to p. 50.

This species is not represented in the present collection or apparently in Dr. van Hoepen's material, but was recorded by Griesbach and Woods.*

\section{Hauericeras? sugata (Forbes).}

1921. Desmoceras compactum, v. Hoepen, loc. cit., p. 21, pl. iv, figs. 5-7, text-fig. 12.

1921. Hauericeras? sugata (Forbes), Spath, Pondoland, p. 46, pl. vi, figs. $3 a, b$.

Dr. van Hoepen's single immature example hardly justifies the creation of a new species, though it is possible that the Pondoland form may not be of the same date as Forbes's type. The writer assumed (loc. cit., p. 54) that Desmoceratids of the group of $A$. sugata have a fairly wide vertical range. Probably derivatives of several desmoceratid stocks, in the present case Schlüteria, successively became carinate and consequently have all been included in this well-known species. There is, however, no satisfactory character to warrant the separation of the immature Pondoland examples from Forbes's species. 


\section{SUB-FAMILY PACHYDISCINAE.}

Genus Parapachydiscus, Hyatt.

17. Parapachydiscus aff. ootacodensis, Stoliczka sp.

(Plate VII, fig. 6.)

1921. Parapachydiscus sp. ind., Spath, loc. cit. (Pondoland), table to p. 50 .

In the description of Parapachydiscus sp. n. aff. colligatus, Binkhorst sp., from Zululand, the writer referred to two large specimens in the present collection, not described by Crick, that " may belong to Parapachydiscus of the colligatus-supremus type." One was described as having "an umbilicus of 19 per cent. and a thickness of 45 per cent. of the diameter," the other as showing " at a whorl-height of $260 \mathrm{~mm}$. a thickness of $200 \mathrm{~mm}$." Both were stated to be more compressed than the Zululand example described, and to be intermediate in sectional outline between fig. 30 ( $P$. colligatus) and fig. 31 ( $P$. oldhami) in Nowak.*

The larger fragment (C 19439) is described above as Parapuzosia haughtoni, sp. n., since development of its dorsal area has shown that the resemblance of its smooth outer whorl to the Parapachydiscus here described was only superficial. The smaller example (No. C 19438), also labelled "Pachydiscus sp." by Crick and not described, has the following dimensions :

$$
\text { at diameter }=150 \mathrm{~mm} ., \cdot 50, \cdot 45, \cdot 19 \text {. }
$$

At the diameter of $59 \mathrm{~mm}$. the whorl-height $=29 \mathrm{~mm}$, and the thickness $=31 \mathrm{~mm}$. ; on the other hand, where the height of the outer whorl $=150$ $\mathrm{mm}$., the thickness is only $125 \mathrm{~mm}$., so that whereas, at first, the whorlsection is round or slightly depressed, with increase of size it becomes compressed. The specimen is still septate at this stage.

$P$. ootacodensis shows a similar change of proportions, with age, i.e. from the more inflated inner whorls (Stoliczka's fig. 4 of pl. liv) to the more compressed adult figured by Stoliczka on pl. lvi. The ribbing also is similar, though the inner whorls seem more distinctly costate in the Pondoland form, almost as strongly ornamented as those of the much more inflated $P$. sp. n. aff. colligatus, figured by the writer. The present form is thus transitional to the more coarsely ornamented $P$. grossouvrei (Kossmat) $=$ $A$. ootacodensis, Stoliczka, pl. lvii, non cæt., but none of the ribs reaches to the umbilical border. The umbilical edge is perhaps not quite so marked as it is in Kossmat's smooth Indian example. $\dagger$

The suture-line differs from that of $P$. ootacodensis in having the four

* Loc. cit. (1913), pl. xliii.

† Loc. cit. (1898), fig. $1 b$, pl. xvi (xxii). 
bifid, outer saddles gradually and regularly decreasing to the umbilical border. The four or five inclined simple saddles of the umbilical wall also slope down to the umbilical suture more regularly even than those of P. tweenianus (Stoliczka).*

\section{Parapachydiscus simplex, v. Hoepen sp.}

1921. Pachydiscus simplex, v. Hoepen, loc. cit., p. 25, pl. v, figs. 3 and 4, text-fig. 14.

This species, belonging to the ganesa-cricki group of Parapachydiscus (see ante, p. 132), is not represented in the present collection.

\section{Parapachydiscus umtafunensis (Crick MS.), Spath.}

(Plate IX, figs. $4 a, b$.)

1921. Spath, loc. cit., Zululand, p. 229, footnote 5.

1921. „, ", Pondoland, p. 49.

This species, represented by the two examples (Nos. C 19434-5) of dimensions $75-.35-\cdot 36-.40$ and $72 \cdot 5-\cdot 34-\cdot 35-\cdot 39$, already referred to by the writer, at first sight seems identical with $P$. antecursor, v. Hoepen sp., but has Th $>\mathrm{H}$, whereas v. Hoepen's single example is described as having the whorl-thickness equal to or less than the height. The real difference, however, appears to be in the suture-line, that of the present species showing very good agreement with the suture-lines of the South American forms of the group of $P$. hauthali, Paulcke sp., and especially with that of $P$. amarus, Paulcke sp. $\dagger$

$P$. tweenianus (Stoliczka), to which the species had been compared by Crick, has a different type of ornamentation.

\section{Parapachydiscus antecursor, v. Hoepen sp.}

1921. Pachydiscus antecursor, v. Hoepen, loc. cit., p. 24, pl. v, figs. 1 and 2 , text-fig. 13 .

This species was compared by its author to a number of pachydiscoid developments, of which only $P$. tweenianus (Stoliczka) is distantly related. In this species, however, the ribbing increases in strength, relatively, on the outer whorls, and the inner whorls are smooth.

* Loc. cit. (1865), pl. lv, fig. $1 b$.

$\dagger$ †Ceph. d. Ob. Kreide Südpatagon.," Ber. Nat. Ges. Freiburg., xv, 1907, p. 62, text-fig. 29 . 


\section{Parapachydiscus? sp. nov.?}

1921. Spath, Pondoland, p. 48 , pl. vii, figs. $5 a, b$.

This form, possibly a young Kitchinites, is not an immature example of one of the species of Parapachydiscus described above, but is too small for accurate identification.

\section{SuB-FAMILy KOSSMATICERATINAE.}

Genus Madrasites, Kilian and Reboul.

22. Madrasites natalensis (Crick MS.), Spath.

$$
\text { (Plate V, fig. 3.) }
$$

1921. "Cret. Ceph. fr. Zululand," Ann. S. Afr. Mus., xii, pt. vii, No. 16, p. 300 .

1921. “Up. Cret. Amm. fr. Pondoland," Ann. Durban Mus., iii, pt. 2, table to p. 50.

This species is based on a well-preserved specimen (No. C 19432) of dimensions $81-\cdot 34-\cdot 40-30$. It shows the aperture well, like the form of Madrasites described below, and was characterised, in the writer's previous papers, as being closely allied to $M$. faku, van Hoepen sp. The latter has a smaller umbilicus and coarser costation therein, and the suture-line is drawn with comparatively simple elements, whereas in the present species it is as ramified as that of Grossouvrites gemmatus (Huppé in Steinmann). Mr. Crick's long original description is not now given, since fig. 3 of Plate V will show how close the present species is to $M$. faku, v. Hoepen sp.

23. Madrasites acuticostatus (Crick MS.), Spath.

$$
\text { (Plate VIII, fig. 2.) }
$$

1921. Spath, Zululand, p. 300.

1921. " Pondoland, table to p. 50.

This species is represented by a single well-preserved example (No. C 19433) of dimensions $100-37-36-28$, and was described at length by Mr. Crick as Holcodiscus acuticostatus. It may suffice to quote the following sentence :-

"Compared with the previous species (H. natalensis), the present species has a relatively coarser sculpture on the inner, and a finer sculpture on the outer, whorls; it is also a more compressed shell, with a wider umbilicus, and a larger number of tubercles on the umbilical margin." 
24. Madrasites faku, v. Hoepen sp.

1920. Holcodiscus faku, v. Hoepen, loc. cit., p. 144, pl. xxv, figs. 3-4, pl. xxvi, figs. 1-2.

1921. Madrasites faku (v. Hoepen), Spath, loc. cit., p. 47, and table to p. 50 .

This species is close to the last two, as pointed out by the writer on a previous occasion.

25. Madrasites africanus, v. Hoepen sp.

1920. Holcodiscus africanus, v. Hoepen, loc. cit., p. 146, pl. xxvi, figs. 3-5. 1921. " " " " loc. cit., p. 23.

1921. Madrasites africanus (v. Hoepen), Spąth, loc. cit., p. 48, and table to p. 50 .

This was compared by the writer to $M$. buddhaicus (Kossmat), from which it differs merely in proportions.

26. Madrasites aff. africanus, v. Hoepen sp.

1921. Holcodiscus africanus?, v. Hoepen, loc. cit., p. 23.

A specimen of Madrasites was described by Dr. var Hoepen as being relatively thicker than $M$. africanus and showing other differences.

\section{Madrasites sp. ind.}

1906. Holcodiscus sp., Woods, loc. cit., p. 336, pl. xlii, fig. 2.

1921. Madrasites sp. ind. (Woods), Spath, Pondoland, p. 48, and table to p. 50 .

This form has a smaller umbilicus and finer ornament than $M$. africanus. It was compared to Jacobites anderssoni by Kilian and Reboul,* and shows, indeed, close resemblance in the inner whorls to the form figured by these authors on pl. vii, fig. 2, if one may judge by Professor Kilian's casts of his Antarctic specimens in the British Museum. Nothing like the adult Jacobites, however, seems to have been found in Pondoland, so that Mr. Woods's form is here considered to be nearer to the typical Madrasites madrasinus (Stol.).

28. Madrasites similis, Spath.

1921. Spath, Pondoland, p. 48, pl. vi, fig. 1.

This form was described as standing in the same relationship to (the tuberculate) $M$. faku as Kossmaticeras sparsicostatum (Kossmat) does to (the costate) $K$. theobaldianum (Stol.).

* “Céph. Néocrét., etc.," Wiss. Ergeb. Schwed. S. Pol. Exp., iii, 6, 1909, pp. 62-3. 


\section{InCertae Sedis.}

Genus Hoploscaphites, Nowak.

At least four species of this genus have been described, but the examples are mostly too fragmentary or too immature to allow of definite specific identifications.

29. Hoploscaphites sp. (cf. similaris, Stoliczka?).

1906. Scaphites sp., Woods, loc. cit., p. 343, pl. xliv, figs. $8 a-c$.

30. Hoploscaphites sp. (cf. pavana, Forbes?).

1921. Scaphites cunliffei. v. Hoepen (non Forbes), loc. cit., p. 28, pl. v, figs. 5-7, text-fig. 16 .

? 1921. Hoploscaphites sp. juv., Spath, Pondoland, p. 49.

31. Hoploscaphites sp. nov.?

1921. Scaphites sp., v. Hoepen, loc. cit., p. 29, pl. v, figs. 8, 9.

32. Hoploscaphites sp. ind.

1921. Scaphites sp., v. Hoepen, loc. cit., p. 30.

\section{FAMILY PRIONOTROPIDAE.}

Genus Mortoniceras, Meek.

33. Mortoniceras soutoni, Baily sp.

(Plate VII, fig. 4.)

1921. Spath, loc. cit. (Zululand), p. 234, pl. xx, fig. 4.

1921. v. Hoepen, loc. cit., p. 38, pls. x, xi, text-figs. 19-22.

1921. Spath, loc. cit. (Pondoland), table to p. 50.

Of the twelve specimens referable to the group of $M$. soutoni, five are too fragmentary to be definitely identified with any of the types mentioned below, but the remaining examples show great variability, as do the specimens described by Dr. van Hoepen. The specimen (No. C 19441) referred to as close to Baily's type, the suture-line of which was figured by the writer,* seems to be the most typical, though it has a considerable number of bifurcating ribs. A fragment (C 19469) is probably also close to the type, whereas

* Loc. cit. (Zululand, 1921), pl. xx, fig. 4. 
specimen C 19461 is nearer to the (at a corresponding size) slightly less closely costate and more evolute example figured by Woods. In this last specimen (C 19461) the costation is regular, single, and relatively closer on the inner whorls; in the first (C 19441) the beginning is more distantly costate, and closeness of the ribbing and bifurcation set in only at a later stage.

A still more closely costate type than C 19461 is C 19442, but here the sharp umbilical edge of the holotype is lost on the outer whorls. The sutureline of this example is figured on Plate VII, fig. 4. C 19454 has a more distantly costate beginning even than C 19441, but otherwise is a characteristic M. soutoni. Specimen C 19451, on the other hand, in which the distant costation of the inner whorls persists to a comparatively late stage, and which also has a more inflated outer whorl, is transitional to $M$. aff. umkwelanense, Crick, described by the writer.* Still another and more evolute form (C 19460) has the costation of the outer whorl more distinctly reclined than the holotype or other examples. Finally, No. C 19447, similar in the inner whorls to the example figured by Woods, has costation simple on the outer whorl and more distant than the ribbing of any other specimen.

The Zululand form described by the writer as $M$. aff. soutoni is not represented in the present collection.

\section{Mortoniceras stangeri, Baily sp}

(Plate IX, fig. 2.)

1921. Spath, loc. cit. (Zululand), p. 297.

1921. , , , (Pondoland), table to p. 50.

Thirty-one examples, including a few impressions and plaster-casts thereof, are referable to this species and its varieties, the great majority of the examples being close to the specimen figured by Woods and to Baily's holotype (Geol. Soc. Coll., 11366) and two paratypes (11367 and 68). They include specimens C 19440 and C 19443, the suture-lines of which were figured in text-figs. $1 c, 1 b$ of the writer's Zululand paper (p. 297), and C 19459, of which a sectional outline of the inner whorls and the internal suture-line were given (loc. cit., pl. xxiii, figs. $3 a, b$ ).

The dimensions of Baily's types are :-

Holotype (11366). Paratype (11367). Paratype (11368).

Diameter . . $\quad 320 \mathrm{~mm}$. $\quad 101 \mathrm{~mm}$. $\quad 115 \mathrm{~mm}$.

Height of outer whorl . 26 per cent. 31 per cent. 27 per cent.

Thickness of outer whorl 19 ", 31 , 27 ,

Umbilicus • • . 56 " 47 ", 51 ,

* Loc. cit. (Zululand, 1921), p. 234, text-fig. D 2, p. 297. 
The outer whorl flattens out in all the large examples, but the two quadratewhorled paratypes do not quite agree in ornamentation either with the holotype or with each other. No. 11367 is transitional to the var. sparsicosta, described below, and has a very indistinct median lateral tubercle ; in 11368 this tubercle is as pronounced as in the example figured by Woods.

35. Mortoniceras stangeri (Baily), var. sparsicosta, nov.

$$
\text { (Plate V, fig. 1.) }
$$

In some of the examples of $M$. stangeri, described above, the inner whorls are less closely costate than in the type. These are transitional to the present variety, which is characterised by the comparatively coarse and distant tuberculation of the inner whorls, and the depression until a fairly late stage of the whorl-section. Baily's paratype $11368 \mathrm{~A}$, the internal suture-line of which was figured on pl. xxiii, fig. $3 c$, of the writer's Zululand paper, also specimen No. C 19444 (text-fig. 1a, p. 297, loc. cit.), belong to this variety. The lateral view of the latter specimen is represented in fig. 1 of Plate V, and has dimensions : 295-.27-.25-.53.

Crick included specimen C 19444 in what he listed as an "intermediate group between $M$. stangeri and $M$. soutoni," but none of the examples in his list has any resemblance to $M$. soutoni. Moreover, there is no description of any of these Mortoniceras, and even the most typical example of $M$. soutoni was erroneously listed as $M$. stangeri.

\section{Mortoniceras stangeri (Baily), var. densicosta, nov.}

$$
\text { (Plate V, fig. 2.) }
$$

This is a more finely costate variety, typically represented by specimen C 19456, here figured, of the following dimensions: $125-\cdot 28-\cdot 25-52$. The inner whorls of this specimen also seem more compressed, though slightly crushed. Some transitional examples (C 19450, C 19450A, C 19462) connect this variety with the typical $M$. stangeri, just as this again is connected by a series of gradations with the var. sparsicosta. The outer whorls of the three forms here described are very similar, and tend to weaken the tuberculation of the costae.

The occurrence of distantly and closely ribbed varieties is of interest in connection with a recent paper by Professor Salfeld.* In the varieties of $M$. stangeri, however, there is no correlated change in whorl-section, and the var. densicosta is not so common as the other forms, being typically

* "Bemerkungen zu v. Bubnoff, etc," Zeitschr. f. indukt. Abstamm. und Vererb. Lehre, 1921. 
represented by only one example. The writer is of opinion that the common occurrence of these types of variation in Ammonites (not mutations, since, apparently, they are contemporaneous) may be taken to indicate a form of "dimorphism," or rather of "polymorphism." The "polymorphism," however, necessitates agreement in the other characters, which would have to be ascertained to exist in a larger number of specimens than are available in the present instance. Moreover, it is difficult to stipulate what would be agreement in, e.g., the suture-lines ; and since the change of a speciesgroup into another and later one occurs by means of adaptive radiation, graphically represented by fans or a multitude of more or less radiating lines rather than by a single line in the customary genealogical tree, opinions would differ greatly as to the "agreement" in a given species-group. The fact that the adult whorls of the various forms here discussed become similar, but not "catagenetic," shows that this "polymorphism" is a phenomenon quite different from the simplification of the ornament on the outer whorls of many Ammonites, which may tend to perfection of adaptation in, e.g., Oxynoticeras, and which often, like the approximation of the last few septa, marks only the slackening of growth on reaching maturity, but which, also, may be simply correlated with the overlap of the mantle in the mature stage.

Genus Pseudoschloenbachia, Spath.

37. Pseudoschloenbachia umbulazi, Baily sp.

(Plate VI, fig. 5.)

1921. Pseudoschloenbachia umbulazi (Baily), Spath, Zululand, p. 240, pl. xx, fig. 2, text-fig. B, p. 241.

1921. Schloenbachia umbulazi (Baily), v. Hoepen, loc. cit., p. 35, pl. viii, figs. 6-9, pl. ix, figs. 1 and 2.

1921. Pseudoschloenbachia umbulazi (Baily), Spath, Pondoland, table to p. 50 .

The measurements of typical examples agree with those given by Dr. van Hoepen, e.g. No. C 19427 has dimensions 50-.52-.28-.14. The inner whorls of this example were figured by the writer (loc. cit., text-fig. B1, p. 241). They show that at a diameter of $32 \mathrm{~mm}$. the thickness $=30$ per cent., and the umbilicus $=18$ per cent., so that the whorls become relatively thinner with age, whereas the umbilicus narrows. At a diameter of $21 \mathrm{~mm}$. the thickness has increased to 33 per cent. In the var. acuta, at the same diameter, the whorl-thickness is only 26 per cent.

The writer has pointed out that these Pondoland examples represent more strongly ornamented varieties, with increasing tuberculation round 
the umbilicus. This is partly due to the larger size of the Pondoland examples; for at a size corresponding with that of the geno-holotype, figured on pl. $\mathrm{xx}$, fig. 2, of the Zululand paper, the umbilical tuberculation of the present specimens is pushed back to only a very slightly earlier stage. The term variety, thus, is hardly applicable to these forms. In example No. C 19426, however, here figured (Plate VI, fig. 5), of dimensions 46$.52-\cdot 29-13$, the umbilical tubercle is decidedly more distinct than in the neotype, which seems to agree in this respect with Baily's lost holotype. Dr. van Hoepen's figs. 1 and 2 of pl. ix represent a similar form. This was again selected as neotype by Dr. van Hoepen, but the writer had fixed the geno-neotype just previously. This form is transitional from the true $P$. umbulazi to the species described below as $P$. pseudofournieri, and thence to $P$. papillata.

The new Egyptian species of Pseudoschloenbachia, mentioned by the writer on previous occasions and figured on Plate V, fig. 4, as P. humei, nov., ${ }^{*}$ is distinguished from $P$. umbulazi by more distinct costation and tuberculation, especially at the ventro-lateral edges. This Egyptian specimen is preserved as a chalcedonic cast, resembling the mode of preservation of a cast in flint of a new Sphenodiscus, allied to S. acutodorsatus, Noetling, from beds of the same age near Jerusalem (B.M. C 22136).

Specimens No. C 19436-7 are associated with Hauericeras gardeni and Mortoniceras stangeri, in addition to other mollusca, in the same blocks.

\section{Pseudoschloenbachia pseudofournieri, nov.}

(Plate VI, fig. 3.)

This species is based on example C 19425 of dimensions 57-.48 -27-.19, referred to previously (Zululand, p. 242) as being slightly constricted and transitional in ornamentation, from $P$. umbulazi to $P$. papillata. It differs from the former in the largeness of its umbilicus and the presence of the constrictions, in addition to the greater strength of its ornamentation, with fewer, but prominent, umbilical tubercles. P. papillata represents a still more coarsely ornamented type, with a yet wider umbilicus. Ornamentation and constrictions of the present species recall Grossouvre's 'Schloenbachia' fournieri, $\dagger$ probably belonging to the genus Gauthiericeras; but the acute periphery of Pseudoschloenbachia and the numerous

* Blanckenhorn's label, in German, attached to this specimen, reads as follows : "Schloenbachia n. sp. ind. aff. varians, yet not two, but three or four auxiliary lobes, i.e. three auxiliary lateral lobes and one umbilical lobe. The first lateral lobe unusually broad-stemmed, deeply bipartite. Cenoman?"

$\dagger$ Loc. cit. (1894), p. 112, pl. xxxv, fig. 1. 
elements of its suture-line are important distinctions from the earlier stock.

P. humei, nov. (Plate V, fig. 4), has more numerous but less prominent inner tubercles, and more distinct and fewer outer nodes.

39. Pseudoschloenbachia papillata (Crick MS.), Spath.

(Plate IX, figs. 1a,b.)

1921. Pseudoschloenbachia papillata (Crick MS.), Spath, Zululand, pp. 240 and 242.

1921. Schloenbachia umbulazi, var. spinifera, v. Hoepen, loc. cit., p. 37, pl. ix, figs. 3-7.

1921. Pseudoschloenbachia papillata (Crick MS.), Spath, Pondoland, p. 43 , pl. vi, figs. $2 a, b$.

This form is sufficiently distinct from $P$. umbulazi to be accorded specific rank.

40. Pseudoschloenbachia griesbachi (Crick MS.), Spath.

(Plate VII, fig. 1 ; Plate VI, fig. 4.)

1921. Pseudoschloenbachia griesbachi (Crick MS.), Spath, Zululand, p. 240, text-fig. B8 on p. 241, p. 312.

1921. Schloenbachia umbulazi, var. griesbachi, v. Hoepen, loc. cit., p. 35 , pl. vii, figs. 3 and 4, pl. viii, figs. 1-5, text-figs. 17-18.

1921. Pseudoschloenbachia griesbachi (Crick MS.), Spath, Pondoland, table to p. 50.

Crick's long description of this species is omitted. The dimensions of the holotype are: $103-.51-.25-.14$; those of the paratype : 33-.52 -26-13. The suture-line of the holotype was figured by the writer on a previous occasion.

\section{INCERTAE SEDIS.}

41. Gen. nov. (Muniericeras?) cricki, Spath.

1921. Loc. cit., Pondoland, p. 44, pl. vii, figs. $4 a, b$.

It is interesting to note that Dr. van Hoepen remarked the resemblance of young examples of Pseudoschloenbachia papillata (his Schloenbachia umbulazi, var. spinifera) to Grossouvre's Muniericeras lapparenti. The tuberculate periphery of the present form, however, separates it from the genus Pseudoschloenbachia, and it may be only a heterochronous homœomorph of the Lower Senonian Muniericeras. 
Genus Eulophoceras, Hyatt.

42. Eulophoceras natalense, Hyatt.

1921. Spath, Pondoland, table to p. 50.

As will be mentioned in the description of Spheniscoceras, Hyatt's form may be only one and an uncommon type of the development separated from Eulophoceras by Crick and again by Dr. van Hoepen on account of minute differences in what appears to be a very variable suture-line.

\section{Genus Spheniscoceras (Crick MS.), Spath.}

1921. Spath, loc. cit. (Zululand), p. 242, text-fig. C 1, p. 243.

Genotype: S. africanum (Crick MS.), Spath, ibid., p. 243, fig. C $1 a$ (Plate VI, fig. 1).

In the original diagnosis this group is described as "intermediate between Placenticeras and Sphenodiscus, Meek," and after giving the characteristics of these two genera Crick continues :

"In the present genus the shell is discoidal, lenticular, with a very small or a closed umbilicus, the sides with obscure radiating ridges; the periphery is acute and usually pinched in a little on either side. The lobes and saddles of the suture-line are rather numerous, but not so many as in Placenticeras and Sphenodiscus. In the suture-line the saddles are feebly incised and have not entire margins as in Sphenodiscus; the external lobe is wide and very deep ; the external saddle is deeply divided by a secondary lobe.

"This genus is represented in the present collection by three [four] examples and a fragment. The examples, which range from 102 to more than $157 \mathrm{~mm}$. in diameter, appear to belong to four different species."

The suture-lines of Crick's three species were figured by the writer on a previous occasion; that of Spheniscoceras cf. amapondense, here reproduced, is of interest in that it has the external saddle less indented than the other "species," and the ventral lobe is very shallow.

The absence of any reference to Eulophoceras, Hyatt, to which genus Crick refers the specimens in 1906 (see Woods, loc. cit., p. 337) is the more remarkable as the four "species" of Crick are very close to Eulophoceras natalense, Hyatt, and it might be held that the development of what may be a thinner keel, and the slight differences in suture-line and ornamentation, are not sufficient to justify the creation of even different species.

The ornamentation of the earlier whorls of Sph. minor has great resemblance to that of Diaziceras; but since the early whorls of $D$. tissotiaeforme are compressed (loc. cit., Zululand, pl. xix, fig. 1c), Spheniscoceras cannot be 
a direct descendant of Diaziceras, but must be looked upon as a more or less parallel development therewith of the normally lobed Pseudoschloenbachia and the form described as gen. nov. (Muniericeras?) cricki, Spath. Eulophoceras, if distinct at all, is a closely similar development. From Hyatt's description, however, it appears that the ornamentation of his somewhat imperfect holotype of Eulophoceras is not strongest at the umbilical and the ventro-lateral shoulders, as in Diaziceras and in the early whorls of Spheniscoceras.

The fact that Dr. van Hoepen, who again created a new genus for the group here discussed, did not record the true Eulophoceras natalense, confirms the writer's opinion that the separation of Spheniscoceras from Eulophoceras is not well founded, and Hyatt's type, which is not well preserved, may represent only an extreme variation.

Lenticeras? jullieni, Pervinquière, which was included in the present stock by Dr. van Hoepen, is here considered to belong to the Coniacian family Tissotidae. It was selected as type of Prelybicoceras, Douvillé,* already in 1912.

The internal suture-line of $S p h$. tenue is here figured for comparison with that of Sphenodiscus, in which genus more pronounced reduction has resulted in monophylloid saddles. This character induced Salfeld $\dagger$ to consider the genus Sphenodiscus and the families Placenticeratidae, Coilopoceratidae, and Engonoceratidae to belong to the super-family Phylloceratida.

43. Spheniscoceras africanum (Crick MS.), Spath.

(Plate VI, fig. 1.)

1921. Spheniscoceras africanum (Crick MS.), Spath, loc. cit. (Zululand), p. 242, fig. C1a, p. 243.

1921. ? Pelecodiscus capensis, v. Hoepen, loc. cit., p. 32, pl. v, fig. 11.

1921. Spheniscoceras africanum (Crick MS.), Spath, Pondoland, table to p. 50 .

The holotype of this species (C 19421) of dimensions 157-.59-.28 -.03, was described in detail by Mr. Crick, but there is now no need to give the original diagnosis. Dr. van Hoepen's small form is doubtfully included here. Its suture-line, however, shows inclination towards the umbilicus, like the suture-lines of the other species mentioned below.

* “Evolut. and Classif. d. Pulchell.," Bull. Soc. Géol. France (4), xi, 1911, fasc. 4-5 (1912), p. 315.

† "Üb. d. Ausgestalt. d. Lob. Lin. b. Jura und Kreide Amm.," Nachr. K. Ges. Wiss. Göttingen, Math.-Phys. Kl., 1919, pp. 8 and 9 (of separate copy). 
44. Spheniscoceras tenue (Crick MS.), Spath.

(Plate VIII, fig. 3 ; Plate VII, fig. 3.)

1921. Spath, loc. cit. (Zululand), p. 242, text-fig. C 1c, p. 243.

1921. , , , (Pondoland), table to p. 50.

This species is represented in the collection by one example, almost completely septate, of the following dimensions: $122 \cdot 5-63-\cdot 23-.00$. Crick described this species in detail, but it is characterised in the one sentence :---

"Besides the differences in the suture-line, this species is easily distinguished both from Spheniscoceras africanum and Sph. minor by its greater compression and much more feeble ornaments."

45. Spheniscoceras minor (Crick MS.), Spath.

(Plate VI, fig. 2.)

1921. Spath, loc. cit. (Zululand), p. 242, text-fig. C 1b, p. 243.

1921. " , , (Pondoland), table to p. 50.

This species was based on specimen C 19422, the dimensions of which are : $102-.64-27-00$. These dimensions were taken at the beginning of the body-chamber. A portion of this is preserved, but is very imperfect. Of Crick's description only the following need be quoted: "At first sight this appears to be an immature specimen of Sph. africanum, but the form of the suture-line does not justify that conclusion. The character of the umbilicus [perfectly closed], as well as the fewness and prominence of the undulations on the inner half of the lateral area, serves also to separate this species from Sph. africanum. The ornaments of the test and the form of the suture-line also distinguish this species from Sph. tenue."

A second example, not noticed by Crick, is enclosed in a block of matrix attached to one of the Mortoniceras, referred to under $M$. soutoni, and considered to be transitional to $M$. aff. umkwelanense (C 19451). The strong ornamentation is even more pronounced in this second specimen.

46. Spheniscoceras amapondense, v. Hoepen sp.

(Plate VII, fig. 2.)

1921. Pelecodiscus amapondensis, v. Hoepen, loc. cit., p. 33, pl. vii, figs. 1 and 2.

A fragment (No. C 19424) in the collection, described by Mr. Crick as 'Spheniscoceras, sp. ind.,' agrees with the smooth outer whorl of the type- 
species, S. africanum, but its suture-line differs from those of the known "species" of this genus, notably in the external saddle. The suture-line of $S$. amapondense is probably nearer than any other to that of the present fragment, but the half of the suture-line of $S$. africanum, opposite to that figured, is also similar, so that by splitting one of these specimens in two still further "species" could be established.

47. Spheniscoceras umzambiense, v. Hoepen sp.

1921. Pelecodiscus umzambiensis, v. Hoepen, loc. cit., p. 30, pl. v, fig. 10, pl. vi, fig. 1.

The suture-line of this form differs slightly from those of the other "species" here recorded.

\section{Family NOSTOCERATIDAE.}

Genus Bostrychoceras, Hyatt.

48. Bostrychocerus? amapondense, v. Hoepen sp.

1921. Bostrychoceras? sp. nov., Spath, Zululand, p. 252.

1921. Heteroceras amapondense, v. Hoepen, loc. cit., p. 17, pl. iv, figs. 1 and 2.

1921. Bostrychoceras? sp. (Woods), Spath, Pondoland, loc. cit., table to p. 50 (Nos. 37, 38).

1921. Diplomoceras? sp. (Woods), Spath, ibid., No. 40.

Genus Diplomoceras, Hyatt.

49. Diplomoceras? indicum (Forbes).

1906. Hamites (Anisoceras) indicus, Forbes; Woods, loc. cit., p. 340, pl. xliv, figs. $2 a, b$.

1921. Diplomoceras? indicum (Forbes), Spath, loc. cit., table to p. 50 (No. 39).

Genus Oxybeloceras, Hyatt.

50. Oxybeloceras amapondense, v. Hoepen sp.

1921. "Hamites" cf. quadrinodosus, Jimbo; Spath, Zululand, p. 255.

1921. Oxybeloceras? sp., cf. interruptum, Schlüter sp., Spath, ibid.

1921. Hamites amapondensis, v. Hoepen, loc. cit., p. 15, pl. iii, figs, 5, 6, text-fig. 9 .

1921. Oxybeloceras? cf. quadrinodosum, Jimbo sp.; Spath, Pondoland, p. 50 , pl. vii, figs. $2 a, b$. 
Genus Neocrioceras, Spath.

51. Neocrioceras cf. spinigerum, Jimbo sp.

1921. Spath, Pondoland, pp. 51-2, pl. vii, figs. 6a-c.

\section{Family BACULITIDAE.}

Genus Baculites, Lamarck.

52. Baculites capensis, Woods.

1921. Spath, Pondoland, table to p. 50.

This species is represented by one example (No. C 19420) of a length of $45 \mathrm{~mm}$.

53. Baculites sulcatus, Baily.

1921. v. Hoepen, loc. cit., p. 18, pl. iii, figs. 7, 8.

1921. Spath, Pondoland, table to p. 50.

\section{Baculites bailyi, Woods.}

1921. v. Hoepen, loc. cit., p. 18, pl. iii, figs. 9, 10.

1921. Spath, Pondoland, table to p. 50.

\section{EXPLANATION OF PLATES.}

PLATE V.

FIG.

1. Mortoniceras stangeri (Baily), var. sparsicosta, nov. Umzamba Beds, Pondoland. B.M., No. C 19444. (Suture-line figured in Spath, loc. cit. (Zululand), p. 297, text-fig. D la.) Reduced $\frac{\dot{a}_{5}}{5}$. (P. 138.)

2. Mortoniceras stangeri (Baily), var. densicosta, nov. Umzamba Beds, Pondoland. B.M., No. C 19456. Reduced $\stackrel{2}{3}$. (P. 138.)

3. Madrasites natalensis (Crick MS.), Spath. Umzamba Beds, Pondoland. B.M., No. C 19432. (P. 134.)

4. Pseudoschloenbachia humei, nov. Near Bir Mellaha, Egypt. No. I, 2288. 4a=sectional outline. (Pp. 140, 141.)

\section{PLATE VI.}

1. Spheniscoceras africanum (Crick MS.), Spath. Geno-holotype. B.M., No. C 19421. Reduced $\frac{5}{8}$. (P. 143.)

2a, b. Spheniscoceras minor (Crick MS.), Spath. B.M., No. C 19422. Lateral and sectional views. (P. 144.)

3a, b. Pseudoschloenbachia pseudofournieri, nov. B.M., No.' C 19425. Lateral view and sectional outline. (P. 140.)

4. Pseudoschloenbachia griesbachi (Crick MS.), Spath. Paratype, B.M., No. C 19429. (P. 141.) 
FIG.

5. Pseudoschloenbachia umbulazi (Baily), var., with more pronounced umbilical tubercles. B.M., No. C 19426. (P. 139.)

6. Tetragonites superstes, v Hoepen. With mouth-border. B.M., No. C 19416. (P. 119.) (All the specimens on this plate are from the Umzamba Beds of Pondoland.)

\section{PLATE VII.}

1 $a, b$. Pseudoschloenbachia griesbachi (Crick MS.), Spath. Holotype, B.M., No. C 19428. Side view and sectional outline. (P. 141.)

2. Spheniscoceras ef. amapondense, v. Hoepen sp. Portion of suture-line, with external and first lateral saddles. $S=$ siphonal line. B.M., No. C 19424. (P. 144.)

3. Spheniscoceras tenue (Crick MS.), Spath. Internal suture-line, enlarged and diagram. matic, at diameter $=115 \mathrm{~mm}$. $\mathrm{A}=$ antisiphonal line. B.M., No. C 19423. (P. 144.) See Plate VIII, fig. 3.

4. Mortoniceras aff. soutoni (Baily). Suture-line of, B.M., No. C 19442, last (?) septum, at about $250 \mathrm{~mm}$. diameter. $\mathrm{S}=$ siphonal line. (P. 136.)

(Specimens 1-4 from the Umzamba Beds of Pondoland.)

5. Canadoceras neuberryanum (Meek). Geno-holotype, British Museum (Geol. Soc. Coll.), Upper Senonian of Vancouver Island. Reduced $\frac{5}{8}$. (P. 125.) See Plate VIII, fig. 4 .

6. Parapachydiscus aff. ootacodensis, Stoliczka sp. Outline-section of inner whorls of specimen C 19438 from the Umzamba Beds of Pondoland. (P. 132.)

\section{PLATE VIII.}

1. Parapuzosia haughtoni, sp. nov. Lateral view of portion of cast of dorsal impression of specimen, B.M., No. C 19439, to show ornamentation of (missing) inner whorl. Reduced $\frac{1}{2}$. (P. 128.)

2. Madrasites acuticostatus (Crick MS.), Spath. B.M., No. C $19433 . \quad$ (P. 134.)

3. Spheniscoceras tenue (Crick MS.), Spath. B.M., No. C 19423. (P. 144.) See Plate VII, fig. 3.

(Specimens 1-3 from the Umzamba Beds of Pondoland.)

4. Canadoceras neuberryanum (Meek). Reduced $\frac{5}{5}$. Peripheral view of specimen figured on Plate VII, fig. 5. (P. 125.)

\section{PLATE IX.}

1 $a$, b. Pseudoschloenbachia papillata (Crick MS.), Spath. Holotype, B.M., No. C 19430. Lateral and peripheral views. (P. 141.)

2. Mortoniceras stangeri (Baily), typus. B.M., No. C 19440 . Reduced about $\frac{2}{5}$. Penultimate septum, figured in Spath, loc. cit. (Zululand), p. 297, fig. D 1 c. (P. 137.)

3a, b. Gaudryceras cinctum (Crick MS.), Spath. B.M., No. C 19415. Lateral view and sectional outline. (P. 118.)

4a, b. Parapachydiscus umtafunensis (Crick MS.), Spath. Holotype, B.M., No. C 19434. Side-end peripheral views. (P. 133.)

(All the examples are from the Umzamba Beds of Pondoland.) 


\section{$2 \mathrm{BHL}$ Biodiversity Heritage Library}

Spath, L F. 1922. "ON THE SENONIAN AMMONITE FAUNA OF PONDOLAND." Transactions of the Royal Society of South Africa 10, 113-147. https://doi.org/10.1080/00359192209519274.

View This Item Online: https://www.biodiversitylibrary.org/item/182861

DOI: https://doi.org/10.1080/00359192209519274

Permalink: https://www.biodiversitylibrary.org/partpdf/175634

\section{Holding Institution}

Smithsonian Libraries

\section{Sponsored by}

Biodiversity Heritage Library

\section{Copyright \& Reuse}

Copyright Status: Not in copyright. The BHL knows of no copyright restrictions on this item.

This document was created from content at the Biodiversity Heritage Library, the world's largest open access digital library for biodiversity literature and archives. Visit BHL at https://www.biodiversitylibrary.org. 